\title{
Business Relationship Framework in Emerging Market: A Preliminary Study in Indonesia
}

\author{
Anton A Setyawan ${ }^{1}$, Basu Swastha Dharmmesta ${ }^{2}$, B.M Purwanto ${ }^{3}$ and Sahid Susilo \\ Nugroho $^{4}$
}

\begin{abstract}
:
This paper explores business relationship framework between two companies. In this research, we use relationship marketing and transaction cost as frameworks to analyze business relationship of two different kinds of companies in Indonesia, oil company and hypermarket. Gronroos (1994) defines relationship marketing is establishing, maintaining, and enhancing relationships with customers and other partners, at a profit, so that the objectives of the parties involved are met. This is achieved by a mutual exchange and fulfilment of promises. This definition is a key to analyze the relationship of retailer and their supplier. In the other side, Williamson (1980) argued that relationship in business organization based on their economic interest. This approach known as transaction cost approach. In this kind of relationship, business organizations consider cost and benefit of business relationship. We use qualitative method in this research. The design of the research is case study with multiple cases proposed by Yin (1994). In this case study, we use basic content analysis as tool to analyze the phenomenon. Unit analysis of this research is company. We use two cases in the different companies, Oil Company and hypermarket. In order to gain validity, we use multiple key person or informant to gain validity. The result shows, that in the oil company, relationship between company and their supplier tied on a strict contract. In fact, the relationship of supplier and a company is based on transaction cost theory. In the hypermarket company, the relationship of supplier and retailer is based on trust, commitment and satisfaction. Those three construct are the foundation of relationship marketing
\end{abstract}

Key Words: Relationship Marketing, Resource Dependence, Transaction Cost Theory, Multiple Case Studies

JEL Classification: M14, M31, O31

\footnotetext{
${ }^{1}$ Faculty of Economic and Business Muhammadiyah University of Surakarta, Indonesia

${ }^{2}$ Faculty of Economic and Business Gadjah Mada University Yogyakarta, Indonesia

${ }^{3}$ Faculty of Economic and Business Gadjah Mada University Yogyakarta, Indonesia

${ }^{4}$ Faculty of Economic and Business Gadjah Mada University Yogyakarta Indonesia
} 


\section{Introduction}

Business relationship of a company with their supplier contribute to its business value. Morgan and Hunt (1994) views modern industrial competition no longer based on company to company competition but network competition. It means that company which have strong network or business relationship will succeed in their business competition. Scholars classifies two different kinds of business relationship, they are relationship marketing and transaction marketing (Paulin, Ferguson and Payaud, 2000; Chaston and Baker, 1998). Alexander and Colgate (2000) suggest company to transform themself from transaction cost approach to relationship marketing. Morgan and Hunt (1994) suggest companies must develop their relationship marketing strategies because it will guarantee long term benefits for them. Gronroos (1994) in the other hand, states relationship marketing is the future of marketing paradigm.

Transaction cost approach in business relationship stress on efficiency. Business relationship with transaction cost approach establish cost efficiency in business process with business partners (Buvik, 2001). Following Willamson (1981) terminology, basic value of this kind of business relationship is business partner has two weakness, they are bounded rationality and opportunism. It means that a company should beliefs that their business partners will take opportunity from weakness in business relationship mechanism. Powell (2004) shows company could prevent opportunity loss by making a strategy execution with transaction cost framework. Powell (2004) executes three scenarios in different approach, perfect rationality, bounded rationality and idle rationality. The result shows transaction cost in perfect rationality assure efficiency in strategic decision making.

This study analyzes business relationship framework in Indonesia, a country which considered as emerging markets. In this study, we analyze oil and retail company as two different cases. Oil industry in Indonesia has become major earnings for the country since 1960's. In 2012, Indonesia government has receive US\$ 34,4 millions from oil industry. In the other hand, retail industry is an emerging industry in Indonesia. This industry contributes more than US\$ 105 million to Indonesia's GDP. There are several major companies in both industries. Kurniati and Yanfitri (2010) clasifies oil and retail in Indonesia in to oligopoly industry. It means that there are few companies exists in both industries.

This study explores framework of business relationship between company and their supplier. It analyze company behavior in establish, develop and maintain their business relationship with suppliers. Design of this study is qualitative with case study approach. The design is multiple case study with two cases, oil company and retail company. Methods of data collection in this study are focus group discussion and in-depth interview. This study examines pattern of business relationship between 
company and their supplier by using content analyses of FGD and in depth interview transcripts.

\section{Theory Development}

\subsection{Relationship Marketing Framework}

Relationship marketing is a framework of business relationship which emerges in the 90's due to the complexity in the industrial competition. Gronroos (1994) identifies there are three reasons involve in relationship marketing development. First, the development of network approach in industrial marketing in Europe. Second, the widen attention of service marketing. Third, there is very strong interest among industries of customer relationship economics. Gronroos (1994) defines relationship marketing as activities to create, develop and maintain relationship with customer and business partner in a mutually benefit relationship. Berry (1983) proposed a different definition of relationship marketing. He defines relationship marketing as attracting and maintaining customer and business partners in the multi service organization. Morgan and Hunt (1994) considered as initial researchers who examine the concept of relationship marketing in an empirical research. Morgan and Hunt (1994) define relationship marketing as establishing, developing and maintaining successful relational exchange.

Hunt and Morgan (1994) in his early works analyze transformation of business strategic in several global companies. They start to use network as part of strategic competition. For example, the emerge of keiretsu in Japan and chaebol in South Korea. Those two kinds of business network play significant role in the success of Asian business in the 90's. Hunt and Morgan (1994) also give several examples of global strategic alliances which define as relationship marketing practice.

Hunt, Arnet and Madhavaram (2006), explain relational factors of relationship marketing. These relational factors are trust, commitment, and cooperation, keeping promises, shared values and communication. In their previous work, Morgan and Hunt (1994) proposed trust and commitment as key mediating variables in relationship marketing. Trust and commitment assure business network reduce the possibility of conflict and tendency to leave the network (Morgan and Hunt, 1994). Trust and commitment are always become basic constructs in relationship marketing research. They become key mediating variables in the relationship between constructs in business network, such as power and business performance (Ramaseshan, Yip and Pae, 2006, Ryu, Min and Zushi, 2008; Thalassinos and Zampeta, 2012), power and economic satisfaction (Dickson and Zhang, 2004), dependence and relational behaviour (Sezen and Yilmaz, 2007), behavioural determinants of supply chain management and business process integration $(\mathrm{Wu}$, 
Chiang, Wu dan $\mathrm{Tu}, 2004)$ and brand satisfaction with repurchase intention (Fullerton, 2005).

Palmer, Lindgreen and Vanhamme, (2005) classifies four schools of thought in relationship marketing. They are Nordic School, IMP (Industrial or International Marketing and Purchasing) Group, Anglo-Australian approach and North American school of thought. Those four schools of thought have different approach in their focus analysis. Central core of Nordic school of thought in relationship marketing are improving quality of relationship marketing, stimulating customer loyalty and extending customer life cycle (Palmer et al, 2005). IMP Group focuses on understanding of organizational relationship of business to business relationships and factors that keep them involves in long term business relationship (Palmer et al, 2005). Anglo Australian approach focuses on quality, customer service and marketing, while North American rely on dyadic approach in their analysis especially company-customer relationship (Palmer et al, 2005). In this research, our framework of relationship marketing focuses on the existence of trust and commitment in the business relationship of selected companies.

\subsection{Transaction Cost Conceptual Framework}

Transaction cost is cost as a result of economic exchange between two parties which vary independent of the competitive market of the goods and service involved in the exchange process (Husted and Folger, 2004). Williamson and Ouchi (1981) revealed that transaction cost occurred due to two basic assumption of individual behaviour in the organization. First, individual has bounded rationality. This condition could results high possibility of failure in decision making or planning activities in the organization. Second, individual tends to have opportunistic behaviour. This situation often arises when individual has certain power in the organization. Transaction cost originally based on individual behaviour; however this framework has been developed to explain organizational behaviour.

In the real business conditions, company has never been facing competitive market and also in a business relationship there is always difference performance between partners. Powell (2004) identifies these conditions due to economic, cultural and historical barriers which may include economics of scale and transaction costs. Transactional cost business relationship based on rational, economic and utilitarian criteria of business transaction (Paulin et al, 2000). Buvik (2000) proposed there are three core of transaction cost, they are specific assets, the internal uncertainty during transaction process and the frequency of goods and services exchange between buyer and seller.

Business relationship which includes two companies or more occurs due to resource sharing or exchange. In the process, there is always possibility of transactional risk which may occured. This risk involves potential failure on business contract 
fulfillment (Pache, 1998). To minimize transactional risk all business relationship should be based on strict legal business contracts. In many cases, it is almost impossible to wrote a completed contract in business relationship due to limitation of individual cognitive ability (Pache, 1998). Opportunistic behavior by business partners could increase due to this situation. Opportunistic behavior of partners emerge as a result of weakness in business contract or business agreement. Therefore, opportunistic behavior appear as a form of assymetric information (Pache, 1998).

Business organizations make their policy in their relationship with partners based on their interest in protecting themselves from transaction risk. Those transactional risks emerge as a result of opportunism behaviour and limited rationality of partners. Business policy to prevent such transactional risks is a reason of transaction costs. Business relationship research with transaction cost framework often focuses on how companies minimizing transaction cost, such as performance evaluation of partners (Bertrand and Meschi, 2005; Brothers and Nakos, 2004), control and power of partner business policy (Pache, 1998; Harvey and Novicevic, 2002) and sharing resources (Nedham and de Kam, 2004). Business relationship with transaction cost approach always has a strict business agreement, this include detail contract, partnership rules and legal punishment for violation against partnership.

\section{Research Methods}

The design of this research is qualitative design with case study. Case study of this research is holistic case study proposed by Yin (1994) and Kohlbacher (2005). Holistic case study views broad aspects of factors related in certain industries.

Yin (1994) proposed that the depth of analysis of phenomenon is more important than quantity of respondents. In this research, we employ multi case design in order to achieve robustness of the result. Subjects of this study are two companies with different characteristics; they are oil and retail companies.

\section{Results and Discussion}

\subsection{Case 1. Oil and Gas Company}

Oil and gas industry in Indonesia is strategic industry which protected by the government. This industry should follow 2001 Oil and Gas Act to make sure that process of exploitation and distribution do not harm Indonesia economic structure. This regulation should be upheld since oil and gas still receive price subvention, as the consequence all activities in this industry based on very strict documents. 
Our first subject of this case study is MEPI (Medco Energy Petroleum Indonesia) Petroleum one of major oil and gas company in Indonesia. This company has more than 1000 employments. Core business of MEPI Petroleum is exploration and distribution of oil and gas. We accomplish focus group discussion with production manager of MEPI Petroleum with their staff. MEPI Petroleum has suppliers which serve company with supporting function of oil and gas exploration, such as transportation, information technology, and catering and sanitation service. Our key respondents are production manager and his staff. Production manager of MEPI Petroleum responsible for IDR 300 million to 50 billion outsourcing contract, while his staffs deal with IDR 50 million to 1.5 billion project for business partners.

MEPI Petroleum offer project for supplier by announce it on their website, furthermore candidates of supplier sent their letter of interest through e-mail. Selected candidates will be contacted to submit their specific document which includes past experience and price. Officers from BP Migas (public organization responsible to coordinate oil companies of Indonesia oil and gas industry) supervised process of project tender. Those officers make sure that there is no collusion or business fraud in the project tender.

There are several requirements for suppliers in MEPI Petroleum. Those include:

- Suppliers must have distinctive competence and experience.

- Suppliers must have branch office located in the project.

- Suppliers must meet minimum financial capacity required by each project.

- All legal documents and certificate must meet Indonesia oil and gas standard of safety.

Suppliers succeed in the project tender are those who offer lowest price. Our key respondents assume that lower price with similar quality of service means efficiency for MEPI Petroleum. We discuss concept of trust in the beginning of focus group discussion with key respondents. They come up with statement:

"We trust our suppliers since they have meet our requirement, but we have to build our business relationship with legal contract to fulfill BP Migas requisite. However, instead of writing a detail contract ours tend to be very loose and flexible. There are only 30 pages of contract agreement. It is very thin compare to other oil company which usually writes more than 150 pages of legal contract. Our company and suppliers believe that strict contract could result difficulties in the execution process and it have potential conflict in the legal agreement".

Those statements show that MEPI Petroleum protects their exchange transaction with legal contract to prevent transaction risks. However, their legal contract is flexible for modification on the behalf of both interests. 
MEPI Petroleum evaluates their supplier's commitment by their performance quality. If supplier's performance meets their business agreement then they will be considered to have commitment to business relationship. MEPI Petroleum production managers give statement about commitment to business relationship:

"We consider that our supplier has commitment to business relationship from our monthly project evaluation. If they meet our requirement then we assumed they have commitment to our business relationship".

One of production staff gives following statement:

"Our suppliers are important partners for our business; we always make sure that in the end of a project they will receive adequate profit for their business. We believe that if our suppliers achieve sufficient performance it will also affect our business performance".

Tellefsen and Thomas (2006) proposed commitment in business to business setting based on benefit calculation. It means that organization commit to any business relationship depends on economic benefit. Tellefsen and Thomas (2006) proposition works in the case of MEPI Petroleum.

There are few interesting findings in the discussion of satisfaction and loyalty to business relationship. Loyalty to business relationship is impossible for either suppliers or MEPI Petroleum. In the 2001 Oil and Gas Act, there is certain rule that forbid a supplier to obtain similar contract in 3 times respectively. Violation against this regulation could result a corruption or collusion accusation. Satisfaction could not result loyalty since MEPI Petroleum should follow Indonesia oil and gas regulation.

Our key respondent, MEPI Petroleum production manager has a statement related to satisfaction issue:

“Our evaluation to supplier's performance often result satisfaction, but we cannot continue our business agreement since we have to follow 2001 Oil and Gas Act. Sometimes, it became dilemma for us, on the one hand we believe that certain suppliers who have experience could improve our performance, but in the other hand if we extent our contract, we will facing a collusion acquisition from BP Migas. It is really a difficult situation for us".

MEPI Petroleum evaluates their supplier's business performance based on their efficiency. It includes cost efficiency and delivery time. They have interest to their supplier's efficiency since it related with company's business performance. Retail industry evaluates business performance as a result of business relationship based on 
profit and sales improvement. In fact those two factors become performance indicators for business relationship evaluation.

\subsection{Case 2. Retail Company}

Our second subject of this case study is Assalam Hypermarket a retail company with large network of suppliers in Surakarta. This retailer founded in 2001. In the beginning, this retailer was a joint venture of national large retailer with local retailer in Surakarta, but in 2005 those business agreement was split and ownership of this retailer has shifted to large Islamic business group in Indonesia.

There are more than 200 suppliers of Assalam Hypermarket. Those suppliers vary from large company to small to medium enterprise (SME) with different product lines. There are certain procedures to join as suppliers to Assalam Hypermarket. First, applicant must present a proposal which shows their proficiencies as suppliers, and then retailers will carry out a verification process which includes inspection of supplier plants, quality assurance, and price and suppliers legal aspects. There are certain requirements for suppliers in Assalam Hypermarket. They are:

- Supplier's product must have bar code, content information and expired date information.

- There should be a guarantee form suppliers about product availability.

- Suppliers must have completed legal aspect documents, such as company license of operation, tax license and bank accounts.

We conduct several in-depth interviews to gain information about Assalam Hypermarket business relationship with it suppliers. We choose two key respondents in the in-depth interviews, they are, Assalam Hypermarket purchasing manager and his senior purchasing staff. We consider both of them have deep knowledge about retailer business relationship based on their experiences. We completed in-depth interview process in 2 months.

Concept of trust in Assalam Hypermarket business relationship depends on partner's competence in the exchange process. Contract or business agreement document were absence in supplier-retailer relationship in the case of Assalam Hypermarket. Our key respondents agreed that trust to suppliers is a result of competence and reputation of supplier is reliable:

"To trust our suppliers means our suppliers has never disappointed us in fulfilling their obligations as we agree. There is no rigid contract document tied our business relationship with suppliers, all of those procedures based on trust. The only document that proofs our buyer-seller relationship is only purchasing receipts". 
Commitment in the business relationship for Assalam Hypermarket depends on economic motivation of each party. Economic motivation in business relationship related with company revenue and profit as result of the agreement. Both parties avoid any conflicts and if it appears then it should be solved immediately. Our key respondent, Assalam Hypermarket senior staff of purchasing gives a statement about this issue:

"We believe that as long as both parties receive increasing profit and revenue from business relationship, they will keep their commitment to fulfil their obligations".

Assalam Hypermarket purchasing manager also gives statement about commitment: "Our suppliers are always keeping their commitment as long as we fulfil our obligations, such as maintain payment procedure on schedule and price agreement".

Leverin and Lilijander (2006) argue relationship marketing improve satisfaction and loyalty of customers. We proposed satisfaction and loyalty as a result of relationship marketing strategy. Our question about retailer's satisfaction has been answered by senior purchasing staff of Assalam Hypermarket with this statement: "We show our satisfaction to our suppliers by continuing our business relationship and send them a card with statement of our satisfaction and gratitude with the business relationship".

Our key respondent, purchasing manager of Assalam Hypermarket notifies loyalty with business relationship could be observed by level of supplier termination. In the last 5 years, there is only 1 percent of supplier termination and the decision to end business relationship comes from supplier. Bankruptcy or business transformation is reason of supplier termination.

Assalam Hypermarket define performance indicator of business relationship as profit improvement as a result of business relationship with supplier. Evaluation of supplier performance depends on sales volume appraisal in every 3 months. If a supplier product suffers low sales in 3 months in a role then retailer will decide whether business relationship should be continued or terminated.

\subsection{Discussion}

Two cases in the different industry show several interesting findings. Both companies formulate strategy to protect their business from transactional risk. MEPI Petroleum and Assalam Hypermarket determine specific requirements for their suppliers. However, they have different technical strategy in the procedure. MEPI Petroleum selects their suppliers from a project tender and their business agreement based on legal contract. On the other hand, Assalam Hypermarket choose their suppliers with the same reason with oil and gas company, however their business relationship based on very flexible agreement, in fact their exchange process is only 
derived from buying receipts. Assalam Hypermarket has long term relationship with most of their suppliers. In average, they have been undergoing their business relationship for 5 years, without any conflict. Long term relationship with suppliers is not possible for MEPI Petroleum, since they have been tied with Indonesia oil and gas regulation, which forbid oil and gas company to create stable relationship with selected suppliers to prevent collusion and fraud in the business.

In both cases, trust considered important aspect in maintaining mutual business relationship. Suppliers build trust to those companies based on their competence and relevant experience. Both companies trust their partners based on their performance in fulfilling their obligations. MEPI Petroleum develops their trust to suppliers by evaluating their performance.

Commitment in the business to business relationship based on benefit calculation. Each party in the business agreement commit with their business relationship as long as they obtain benefit. Definition of benefit is level of profit they received from business exchange process. However, there is an interesting finding in Retail Company; commitment has a meaning of understand suppliers concern about their financial performance.

Satisfaction and loyalty in those two cases show different impact to business relationship. In the case of oil and Gas Company, satisfaction with business relationship does not imply it will result loyalty to suppliers, since 2001 Oil and Gas Act forbid long term relationship between oil and Gas Company with its suppliers. However, satisfaction with supplier performance in the retail company will result loyalty and long term business relationship.

Each case has different measurement about company performance as a result of business relationship. Oil and Gas Company determine performance by assessment of cost efficiency as result of relational exchange. On the other hand, Retail Company measures performance by evaluating their profit and sales improvement. Table 1 show difference characteristic of relational exchange construct in each case.

\section{Table 1 Characteristic of Relational Exchange Construct}

\begin{tabular}{|l|l|l|}
\hline Construct & Case 1. Oil and Gas Company & Case 2. Retail Industry \\
\hline Trust & $\begin{array}{l}\text { Trust is a result of supplier's } \\
\text { performance }\end{array}$ & $\begin{array}{l}\text { Trust is a result of fulfilling } \\
\text { promises and honestly of } \\
\text { suppliers. }\end{array}$ \\
\hline Commitment & $\begin{array}{l}\text { Commitment related with degree of } \\
\text { supplier's obedience with project } \\
\text { contract }\end{array}$ & $\begin{array}{l}\text { Commitment is willingness to } \\
\text { stay in business relationship } \\
\text { due to benefit calculation. }\end{array}$ \\
\hline Satisfaction & $\begin{array}{l}\text { Satisfaction does not imply business } \\
\text { relationship sustainability. }\end{array}$ & $\begin{array}{l}\text { Satisfaction could result loyalty } \\
\text { and long term business }\end{array}$ \\
\hline
\end{tabular}




\begin{tabular}{|l|l|l|}
\hline & \multicolumn{1}{|c|}{ relationship. } \\
\hline Loyalty & $\begin{array}{l}\text { Loyalty is not possible since it will } \\
\text { violate oil and gas regulation. }\end{array}$ & $\begin{array}{l}\text { Loyalty is long term business } \\
\text { relationship without any } \\
\text { conflicts. }\end{array}$ \\
\hline Performance & Cost efficiency assessment & $\begin{array}{l}\text { Increasing profitability and } \\
\text { sales volume. }\end{array}$ \\
\hline
\end{tabular}

\section{Conclusion}

This study have focal conclusion about type of business relationship. There are two different types of business relationship for each case. Retail company case has characteristic of relationship marketing type of business relational exchange, while oil and Gas Company tend to transaction cost relationship. However, both cases show an example of transaction risk protection. Oil gas company protect their interest by using a strict contract, while retailer choose to give mutual benefit to their business partners, such as offering a chance to increase profitability and sales volume.

There are different types of trust and commitment in both cases. In the case of retail company, trust and commitment concept proposed by Morgan and Hunt (1994) are relevant to explain business relationship between retailer and their suppliers. In this case, trust and commitment related with satisfaction with partner's performance and loyalty to business relationship.

Trust and commitment in the case of oil and Gas Company have a different characteristic. Trust and commitment related with obedience with business contract. In this case, satisfaction is not related with loyalty since long term business relationship with single supplier could result collusion accusation. Transaction risk in the case of oil company has been protected by 2001 Oil and Gas Act.

This study gives several recommendations for further research in business relationship marketing. The result of this study suggests analyzing role of trust and commitment in a supplier-retailer relationship. Our proposition is trust and commitment are key mediating variable for mutual benefit business relationship between suppler and retailer. Question remarks in the supplier-retailer relationship are how each party control other to commit with their business agreement? What kinds of influence strategy use by each party?

This result a conclusion that whenever an industry protected with strict regulation than there is a tendency transaction cost approach occurred. There is a proposition that this kind of industry have oligopolistic structure. In contrast, high competitive industry tends to employs relationship marketing. Company in the competitive market should build strong business network to achieve competitiveness. This study 
also confirm Palmer (2007) finding that transactional and relational approach is not a continuum. Therefore, this study found that one of factor affected a company to apply transaction cost or relationship marketing approach relies on industry regulation.

\section{References}

Alexander, N., and Colgate, M., (2000), "Retail Financial Services: Transaction To Relationship Marketing”, European Journal of Marketing, Vol. 34 No. 8, 2000, pp. 938-953.

Berry, L.L., (1983), "Relationship Marketing”, American Marketing Association, pp . 25-28

Bertrand, P. and Meschi, P.X. (2005), "A Transactional Analysis of Chinese Partners' Performance in International Joint Ventures", The Chinese Economy, Vol. 38, no. 2, pp. $16-35$.

Brouthers, K.D., and Nakos, G., (2004), "SME Entry Mode Choice and Performance: ATransaction Cost Perspective", Entrepreneurship Theory And Practice, Spring Edition.

Buvik, A., (2001), "The Industrial Purchasing Research Framework: A Comparison Of Theoretical Perspectives From Micro Economics, Marketing And Organization Science”, Journal of Business and Industrial Marketing, Vol.16 No. 6, pp 439-451.

Chaston I. and Baker, S., (1998), "Relationship Influencers: Determination Of Affect In The Provision Of Advisory Services To SME Sector Firms", Journal of European Industrial Training, 22/6, pp 249-256.

Dickson, M. A. and Zhang. L., (2004), “Supplier-Retailer Relationships in China's Distribution Channel for Foreign Brand Apparel", Journal of Fashion Marketing and Management, Vol. 8 No. 2, pp. 201-220

Fulerton, G., (2005), “The Impact of Brand Commitment on Loyalty to Retail Service Brands", Canadian Journal of Administrative Science, Vol 22 pp 97-110.

Gonroos, C., (1994), "From Marketing Mix To Relationship Marketing: Towards a Paradigm Shift in Marketing”, Management Decision, Vol 32 No 2 pp 4-20.

Harvey, M. and Novicevic, M.M., (2002), "Selecting Marketing Managers to Effectively Control Global Channels of Distribution”, International Marketing Review, Vol. 19 No. 5, pp 525-544. 
Hunt, S.D., Arnett, D.B. and Dan Madhavaram, S., (2006), "The Explanatory Foundations of Relationship Marketing Theory", Journal of Business and Industrial Marketing, Vol. 21 No. 2, pp 72-87.

Hunt, S.D. and Morgan, R.M, (1994), "Relationship Marketing In The Era Of Network Competition”, Marketing Management, Vol 3 No.1 pp 18-28.

Husted, B.W. and Folger, R., (2004), "Fairness and Transaction Costs", Organization Science, 15(6), pp. 719-729

Kohlbacher, F., (2005), "The Use of Qualitative Content Analysis in Case Study Research", Forum: Qualitative Social Research, Vol 7 No 1 January.

Kurniati Y. and Yanfitri, M., (2010), "Dinamika Industri Manufaktur dan Respon Terhadap Siklus Bisnis”, Buletin Ekonomi Moneter dan Perbankan, October, pp 136-158.

Leverin, A. and Liljander, V. (2006), "Does Relationship Marketing Improve Customer Relationship Satisfaction And Loyalty?”, International Journal Of Bank Marketing, Vol. 24 No. 4, pp. 232-251.

Morgan, R.M. and Shelby D.H., (1994), 'The Commitment-Trust Theory Of Relationship Marketing', Journal of Marketing, 58:3, pp. 20-38.

Needham, B. and De Kam, G. (2004), "Understanding How Land is Exchanged: Coordination Mechanisms and Transaction Costs”, Urban Studies, Vol. 41, No. 10, pp. 2061-2076.

Paché, G., (1998), “A Transactional Approach To Global Sourcing: Application To French Food Retailers", International Journal Of Retail and Distribution Management, Volume 26, Number 2, pp. 88-96.

Palmer R., Lindgreen A. and Dan Vanhamme J., (2005), "Relationship Marketing: Schools of Thought and Future Research Directions", Marketing Intelligence and Planning, Vol 23, No 3, pp. 313-330.

Palmer, R., (2007), “The Transaction -Relational Continuum: Conceptually Elegant But Empirically Denied”, Journal of Business and Industrial Marketing, 22/7, pp 439-451.

Paulin, M., Ferguson, R.J. and Payaud, M., (2000), "Business Effectiveness And Professional Service Personnel Relational Or Transactional Managers?”, European Journal of Marketing, Vol. 34, No. 3/4, 2000, pp. 453-471.

Powell. T.C., (2004), "Strategy, Execution and Idle Rationality", Journal of Management Research, Volume 4, No. 2., pp. 77-98. 
Ramaseshan, B., Yip L.C. and Dan Pae, J.H., (2006), "Power, Satisfaction and Relationship Commitment in Chinese Store-Tenant Relationship and Their Impact on Performance", Journal of Retailing, Vol 82, No 1, pp. 63-70

Ryu, S. M. and Dan Zushi, N., (2008), “The Moderating Role Of Trust In ManufacturerSupplier Relationships", Journal of Business \& Industrial Marketing, Vol.23, No. 1, pp. $48-58$

Sezen, B. and Yilmaz, C., (2007), "Relative Effects Of Depen Dence And Trust On Flexibility, Information Exchange and Solidarity In Marketing Channels", Journal of Business \& Industrial Marketing, 22/1, pp. $41-51$

Tellefsen, T. and Thomas, G.P., (2005), "The Antecedents And Consequences Of Organizational And Personal Commitment in Business Service Relationships", Industrial Marketing Management, Vol 34, pp. 23-37.

Thalassinos, I.E. and Zampeta, V. (2012), "How Corporate Governance and Globalization Affect the Administrative Structure of the Shipping Industry", Journal of Global Business and Technology, Vol. 8(1), 48-52.

Williamson, O., (1981), “The Economics Of Organizations: The Transaction Cost Approach, American Journal of Sociology, Vol. 87, No. 3, pp 548-77.

Williamson, O.E and Ouchi, W.G., (1981), "The Market and Hierarchies Program of Research: Origins,Impications and Prospects”, New York: Wiley Interscience.

Wu, W.Y, Chiag, C.Y. Wu Y.J and Dan Tu H.T., (2004), “The Influencing Factors Of Commitment And Business Integration On Supply Chain Management”, Industrial Management \& Data Systems, Volume 104, Number 4, pp. 322-333.

Yin, R. K., (1994), “Case Study Research, Design and Methods”, Sage Publications, London 